doi: $10.26529 /$ cepsj.845

\title{
Editorial
}

\section{Religion, Education, and the Challenges of Contemporary Societies}

Religions have had, and still have, a critical role in shaping the world in which we live. As an ideology, they play a vital role in shaping world politics. In recent decades, we have been witnessing a kind of revival of religion and its re-entry into the public sphere. The context of modern globalisation in tandem with various political, economic, and ecological crises makes Western societies increasingly susceptible to influxes of heterogeneous groups of migrants, who bring with them cultural and religious traditions that are often markedly different from those of the majority of the local populations. The contrast between historically established religious practices and relatively newly established religions, combined with power struggles over the new public role of religion in some countries (especially evident in post-socialist Central and Eastern Europe), is giving rise to complex social challenges, some of which are also manifested in the field of public education. The present issue of CEPS Journal systematically addresses these challenges.

The growing pluralisation of European societies is bringing forth some old questions and opening up new dilemmas. The changing circumstances are probably not eroding the foundations of the modern public school laid during the Enlightenment period; the public school's commitment to secularity and neutrality (while also allowing for private schools with religious or other kinds of worldview affiliation) continues to remain at the core of its purpose in the $21^{\text {st }}$ century. However, some social developments and conflicts of the recent past are undoubtedly opening, repeating and/or worsening a number of difficult questions about the practical application of foundational democratic principles in specific social contexts of individual societies and nation-states.

The old, fundamental question of the presence of religion-related content in school curricula has long been morphed into much more than the simple question of confessional religious instruction (as in catechesis) in public schools. When we discuss religion-related content in the public school today, we also - if not mostly - talk about the different forms of non-confessional education about religion(s). In the contemporary European context, which is marred by growing Islamophobia and the related growth of intolerant and radically exclusionist political (and other) extremisms, the need for a systematic critical introduction of pupils to the complex social and cultural phenomenon that is religion (with all its diversity in today's world) is particularly evident. 
The growing pluralisation also gives rise to the complex problem of religious symbols in contemporary public spaces. With the advent of modern secularity and the increased pluralisation of the $21^{\text {st }}$ century, the marking of school spaces with Christian symbols is no longer self-evidently justified. At the same time, pupils (and to a lesser extent teachers) increasingly enter educational spaces with visible symbols of their minority religious affiliation (e.g., Muslim girls and women wearing veils), which challenges the (until recently) prevailing image of European countries as monolithic societies and also problematises the principle of equality (regardless of cultural differences) ensured by modern democratic societies.

European education systems have adopted different standpoints regarding the way religious belonging among pupils and teachers is dealt with and the kind of knowledge about religions that is communicated in and beyond the classrooms. The situation varies from country to country and is based on particular cultural and legal traditions and consequently on the kind of regulation that is enforced within a given country. In societies in which religion is strictly separated from the state, any kind of religious content, and sometimes also any information about religion, is excluded from teaching. This has often resulted in young people no longer being sufficiently equipped with information about religions and consequently having serious difficulties understanding and critically reflecting on today's dilemmas and conflicts connected to religion. In contrast, in some countries, there has arisen highly confessional teaching that mostly provides students with religious knowledge of one religion only. This is again highly problematic and clearly insufficient to meet the needs of today's world.

The authors of this special issue of CEPS Journal share the conviction that religious education (RE) should be organised on a study-of-religion(s) basis. Our opinions are based on the supposition that the primary goal of public education in the $21^{\text {st }}$ century is to comprehensively familiarise pupils with religion and its diverse manifestations and negotiations in contemporary societies. Furthermore, that aim is achievable only if RE is based on a scientifically informed, value-neutral, and (as much as possible) objective and critical approach. Religion has to be taught in the same way as any other subject in public schools.

We open our thematic issue with the introductory overview of the basic principles of the study-of-religion(s) approach to religious education (RE). In her presentation and critical discussion, Karna Kjeldsen relies on epistemological and methodological bases of the discipline of religious studies or - probably more suitably - the scientific study of religion(s) (but also adding arguments and perspectives of general theories of education). She makes references to her 
own research on 'how Christianity is discussed and represented in political and public debates in Denmark, national curricula, textbooks and the intended teaching of RE teachers (lesson plans, syllabi, other teaching material etc.)' and uses the comparison to History teaching in primary schools (with examples from Sweden and Denmark) to argue that analytical-critical skills (like being able to investigate primary sources, question them rigorously, set them into context and be able to present their produced knowledge') should be the central part of RE in the elementary public school.

We continue with a kind of manifesto: Tim Jensen, veteran researcher and long-time activist in the field of RE, former secretary-general and current president of the International Association for the History of Religions (IAHR), presents his 'programmatic summary' of the basic presuppositions and principles for a scientific study-of-religion(s) based RE as 'a time-tabled, compulsory and totally normal school subject, taught by teachers educated at study-ofreligion(s) departments of public universities' - a paradigm already named by some as 'Jensen's Scientific Approach to RE'. Like the author of the first paper, Jensen intentionally uses the term 'religion education' for this approach in order to distinguish it from the established generic term 'religious education' used for various RE models (non-confessional, semi-confessional and/or fully confessional) by experts, researchers, school authorities, teachers, politicians, etc.

Another vocal advocate of the promotion of a secular approach to religion in school, Wanda Alberts, critically examines contemporary European models of RE and highlights problems that are inherent in the dominant trends. She emphasises that elements of religious notions of religion prevail not only in confessional but also in integrative models (designed for all pupils in religiously heterogeneous classes) and even in so-called 'alternative subjects' for the pupils who abstain from confessional RE. The author calls the combination of the prioritisation of Christian confessional models in combination with the frequently implicitly religious character of non-confessional models 'small-iindoctrination' and warns that this enforces 'an unquestioned discursive hegemony of a particular (Christian) notion of religion as a frame of reference for almost all education about religion' (which is especially problematic when it is represented as a universal perspective and not a particular religious view of religion). She is highly critical about the general lack of secular perspective on religion and religious diversity in European RE and argues that the frequent lack of strict distinction between religious and secular approaches to religion in public school is a serious human rights issue.

Similarly, our next author, Bengt-Ove Andreassen, warns about the nonconfessional models which are very often being 'marinated' in confessional 
religion (a metaphor introduced by Swedish RE scholar Jenny Berglund). He deconstructs the proclaimed general aim of RE to 'serve the promotion of social cohesion by way of promoting knowledge and understanding of the new multi-religious world'. By critically focusing on 'knowledge about religion' in RE (in light of Norwegian curricula developments), he argues for the critical importance of analytical and interpretative skills in RE.

The last two papers expand the issue's focus to include the question of religious symbols in public schools. Christian Moe argues that both questions ( $\mathrm{RE}$ and the use of religious symbols) 'involve the challenge of applying liberal democratic principles of secularism and pluralism in a school setting, and refract policies on religion under conditions of globalization, modernization and migration'. The author takes this situation as a 'teachable moment' and finds in it the potential for the scientific study-of-religion(s) based RE. However, at the same time, he emphasises that 'this requires maintaining a spirit of free, unbiased comparative enquiry that may clash with political attempts to instrumentalise the subject as a means of integrating minority students into a value system'.

In the final paper on the topic, Aleš Črnič and Anja Pogačnik summarise the key issues and debates regarding religious symbols in public schools. They briefly examine how the Muslim veil is managed in select European countries and then focus on a single country and present the specific expert recommendations for managing religious symbols in public schools in Slovenia (thus 'combining a broader, comparative perspective with practical, small-scale policy suggestions'). In their conclusion the authors specifically argue for a 'more principled and inclusive management of religion in public schools.

We round off the thematically focused papers with two reviews of books, covering the same thematic field (both books were reviewed by Anja Pogačnik).

We Need to Talk About Religious Education: Manifestos for the Future of Religious Education (Jessica Kingsley Publishers, 2018) is edited by Mike Castelli and Mark Chater, both former RE teachers and RE curriculum advisers, now involved in executive-level organising of RE in the United Kingdom. The book is academic in nature yet includes more than just individuals with academic experiences. Chapters highlight various aspects of the English RE system, raise a set of fundamental questions about the subject to be considered, and invoke a different path toward a future of Religious Education. Although the book is based on the British/English RE system (which is not immediately apparent from the book's title), the discussed questions and suggestions are generally applicable to other national contexts and 'provide a valuable starting point for a plethora of thinking streams and possible imaginings of the future for Religious Education anywhere.' 
The second reviewed book is a volume edited by Anders Sjöborg and Hans-Georg Ziebert, entitled Religion, Education and Human Rights: Theoretical and Empirical Perspectives (Springer International Publishing, 2017). It grew out of an international workshop and presents a collection of contributions that loosely revolve around the fields listed in the title. Contributing scholars come from a range of different fields and disciplines (including law, theology, religious studies, etc.) and what connects them is a focus on the countries around the Baltic Sea region (Sweden, Norway, Finland, Estonia, Belorussia, Poland, and Germany). While some chapters provide a worthwhile read to those engaged in similar research topics, the book as a whole unfortunately lacks a clear focus in its content and fluctuates widely in the quality of contributing chapters.

In accordance with the profile of the CEPS Journal, the section before the book reviews presents two Varia papers.

In the first one, entitled Promoting Youth Entrepreneurship and Employability through Non-Formal and Informal Learning: The Latvia Case, Tamara Pigozne, Ineta Luka and Svetlana Surikova present some results of their research on adult education resources developed to reduce youth unemployment. The research was conducted using a mixed-method (quantitative and qualitative) approach, and the results reveal a widely shared opinion about the importance of intensive cooperation with employers when organising educational activities among young Latvian adults. The authors also uncover the most and least efficient non-formal and informal learning methods, forms, and initiatives to promote youth entrepreneurship and employability in Latvia.

The second Varia paper was written by Mohammad Salman Fayyad Alkhazaleh and Habes Mohammed Khalifa Hattamleh. They entitled it The Educational Supervisor's Performance in Light of Applying the Knowledge Economy in the Education Directorates of Zarqa Governorate in the Hashemite Kingdom of Jordan and it presents the results of 'the study of the performance of the educational supervisor in the light of applying the knowledge economy in the education directorates of the Zarqa Governorate. Based on these results, the authors also suggest some recommendations.

ALEŠ ČrNIČ 